\title{
Characterization of both myocardial extracellular volume expansion and myocyte mypertrophy by CMR detect early signs of myocardial tissue remodeling in Friedreich's ataxia patients without heart failure.
}

\author{
Otavio R Coelho-Filho ${ }^{1 *}$, Ravi V Shah², Thiago D Venancio ${ }^{1}$, Alberto R Martinez ${ }^{1}$, Tomas G Neilan², Irene Righetti ${ }^{1}$, \\ Cynthia B da Silva ${ }^{1}$, Ingrid Faber ${ }^{1}$, Iscia Lopes-Cendes ${ }^{1}$, Marcondes França $\mathrm{Jr}^{1}$, Michael Jerosch-Herold ${ }^{2}$
}

From 19th Annual SCMR Scientific Sessions

Los Angeles, CA, USA. 27-30 January 2016

\section{Background}

Heart Failure (HF) is the most common cause of death in Friedreich's ataxia (FRDA), a mitochondrial disease characterized by neurodegeneration, hypertrophic cardiomyopathy, caused by homozygous GAA expansions in the FXN gene. Recent report demonstrates that specific-gene therapy may prevent and reverse the cardiomyopathy in a mice model of FRDA. Myocardial interstitial fibrosis is a hallmark of FRDA's cardiomyopathy and a potential substrate for arrhythmias and HF. Myocardial tissue characterization by cardiac magnetic resonance (CMR) allows access to tissue-based phenotypes that may better describe LV remodeling in FRDA's cardiomyopathy.

\section{Methods}

The aim of this study was to perform direct quantification of myocardial extracellular volume fraction (ECV) and intracellular lifetime of water $\left(\tau_{\text {ic }}\right)$, a measure of cardiomyocyte hypertrophy, using T1-weighted CMR imaging in cohort of patients with FRDA without HF.

We investigated 27 FRDA patients without HF (mean age $26.8 \pm 9,12$ female) and in 30 healthy volunteers as control subjects (mean age $49 \pm 15$ ) using a $3 \mathrm{~T}$ CMR system. The T1 quantification by Look-Locker gradient-echo before and after contrast applying a 2-site model for transcytolemmal water Exchange was used for ECV and $\tau_{\text {ic }}$ quantification. Cine CMR and LGE imaging in matching locations were also performed.

\section{Results}

FRDA patients revealed normal LVEF with increased LV Mass-index compared with health controls (for LVEF $67.3 \% \pm 11.5$ vs. $62.5 \% \pm 6.8, \mathrm{P}=\mathrm{NS}$; for LVMASSi $62.7 \pm$ 23 vs. $\left.45.1 \pm 6.8 \mathrm{~g} / \mathrm{m}^{2}, \mathrm{p}<0.05\right)$. In 4 out 27 FRDA patients a non-ischemic LGE pattern was present. Both ECV and intracellular lifetime of water $\left(\tau_{\text {ic }}\right)$ were significantly higher FRDA patients (ECV: $0.36 \pm 0.04$ vs. $0.28 \pm$ $0.03, \mathrm{p}<0.0001 ; \tau_{\mathrm{ic}}: 0.12 \pm 0.08$ vs. $\left.0.08 \pm 0.03, \mathrm{p}<0.005\right)$.

\section{Conclusions}

ECV and intracellular lifetime of water $\left(\tau_{\mathrm{ic}}\right)$ determined by T1 measurements characterized early signs of myocardial tissue remodeling in FRDA with normal LVEF. Early changes in tissue-phenotypes are detectable by novel-CMR methods in FRDA patients, and may be useful to track effects of new genetic therapies for FRDA cardiomyopathy.

\footnotetext{
Authors' details

${ }^{1}$ Medicine, State University of Campinas - UNICAMP, Campinas, Brazil.

${ }^{2}$ Harvard Medical School, Boston, MA, USA.
}

Published: 27 January 2016

${ }^{1}$ Medicine, State University of Campinas - UNICAMP, Campinas, Brazil Full list of author information is available at the end of the article 
doi:10.1186/1532-429X-18-S1-W7

Cite this article as: Coelho-Filho et al:: Characterization of both

myocardial extracellular volume expansion and myocyte mypertrophy

by CMR detect early signs of myocardial tissue remodeling in

Friedreich's ataxia patients without heart failure.. Journal of

Cardiovascular Magnetic Resonance 2016 18(Suppl 1):W7.

Submit your next manuscript to BioMed Central and take full advantage of:

- Convenient online submission

- Thorough peer review

- No space constraints or color figure charges

- Immediate publication on acceptance

- Inclusion in PubMed, CAS, Scopus and Google Scholar

- Research which is freely available for redistribution

Submit your manuscript at 